Original article

https://www.journal-imab-bg.org

\title{
COMPARATIVE EVALUATION OF RISK FACTORS IN YOUNG AND MIDDLE-AGE PATIENTS WITH ACUTE ISCHEMIC STROKE
}

\author{
Georgi Tz. Dimitrov ${ }^{1}$, Maya P. Danovska ${ }^{1}$, Yoana I. Simeonova ${ }^{2}$, Irena I. \\ Gencheva $^{3}$, Plamen G. Stoev ${ }^{1}$, Emilia M. Ovcharova ${ }^{1}$, Diana L. Marinova ${ }^{1}$ \\ 1) Department of Neurology, University Hospital, Medical University, Pleven, \\ Bulgaria. \\ 2) Department of Social Medicine, Faculty of Public Health, Medical University, \\ Sofia, Bulgaria. \\ 3) Department of Clinical Laboratory, Clinical Immunology and Allergology, \\ University Hospital, Medical University, Pleven, Bulgaria.
}

\begin{abstract}
Background: Ischemic stroke (IS) in young adults has different etiologies and risk factors (RF). A better understanding of the contribution of potentially modifiable $\mathrm{RF}$ to the global burden of IS in young adults is crucial for successful prevention strategies.

Objective: To evaluate the incidence and prevalence of different RF in young and middle-age acute IS patients.

Material and Methods: In the study were included 63 patients with acute IS, admitted to the Neurology Clinic Pleven. They were classified in two groups: Group A $(n=10)$ of young (18-44 y) and Group B ( $n=53)$ of middle-age (4559 y) IS patients. Comparative evaluation of the following RF: age, sex, family history of stroke, arterial hypertension $(\mathrm{AH})$, smoking, dyslipidemia, alcohol consumption, low physical activity, obesity and diabetes mellitus (DM) was done. The statistical analysis was performed with the Statistical Package for Social Sciences, version 24.0 (SPSS).

Results: Out of the 63 patients, $42(66,7 \%)$ were males and $53(84,1 \%)$ were $45-59$ years old. No gender difference was found in group A, while in Group B, the prevalence of male patients $(69,8 \%)$ was found, though statistically not significant $(\mathrm{p}=0.223)$. A first-degree family history of stroke had $30(93.8 \%)$ of the middle-aged IS patients, as compared to only 2 of the young ones $(6,3 \%)$, which was statistically significant $(\mathrm{p}=0.034)$. Group B showed prevalence of smoking $(82,2 \%)$, alcohol consumption $(83 \%)$, body overweight $(90,5 \%)$, low physical activity (80\%), AH (87,3\%) and DM (87,3\%).

Conclusion: The higher incidence of some RF in middle-age acute IS patients indicates that early identification and control of the RF is the best strategy for reducing stroke mortality and morbidity.
\end{abstract}

Key words: Ischemic stroke, risk factors, young and middle-age patients,

\section{INTRODUCTION}

Stroke is a leading cause of death, physical and mental disability worldwide. Although stroke has been considered a privilege of the older population, recent data reveals the increasing number of "young" strokes $[1,2]$. The incidence of IS in the age range 18-50 years is 10.8 to 100000 population [3]. Approximately $10 \%$ of the young and middle-age IS patients remain severely disabled, half of them do not return to work with worsen quality of life thus causing serious economic consequences to their families and the society [4]. Annual expenses for treatment and rehabilitation of IS outpatients are assessed to 5.7 billion US dollars [4]. As the treatment of IS remains limited, the best approach to reduce stroke mortality and morbidity is the primary prevention through RF modification.

IS in young adults is considered a multifactorial disease involving genetic predisposition and a number of modifiable factors. The hypothesis that "young" stroke is associated only with rare RF is still under debate [1]. Regardless of the cumulating information that well-defined traditional RF are widely present in young male patients, undoubtedly IS in young adults has different etiologies and risk factors (RF) from the older population.

Although most of the RF for IS are potentially modifiable (smoking, low physical activity, irrational nutrition, alcohol consumption, dysplipidemia, hyperhomocysteinemia, asymptomatic carotid stenosis, AH, DM and others), their control and management are still a medical and social challenge.

For the purpose of primary stroke prevention in young adults, a multidisciplinary approach, integrating innovative screening and educational programs for early identification and control of the specific modifiable RF, is recommended $[3,4,5]$.

The aim of the present study was to evaluate the incidence and prevalence of different RF in young (18$44 \mathrm{y})$ and middle-age (45-59 y) acute IS patients. 


\section{MATERIALS AND METHODS}

In the prospective study initially were enrolled 80 patients with acute IS admitted to the Neurology Clinic of UMHAT "Dr Georgi Stranski” Pleven from September 2018 to September 2019. From the study were excluded 17 patients with rhythmic disorders, concomitant systemic, infectious and psychiatric diseases. The remaining 63 patients that fulfilled the inclusion criteria of the study were subdivided into two groups: Croup A $(n=10)$ with age range 18-44 years and Group $B(n=53)$ with age range 45-59 years. All the patients were diagnosed with first or recurrent acute IS.

Fig. 1. Family history of IS

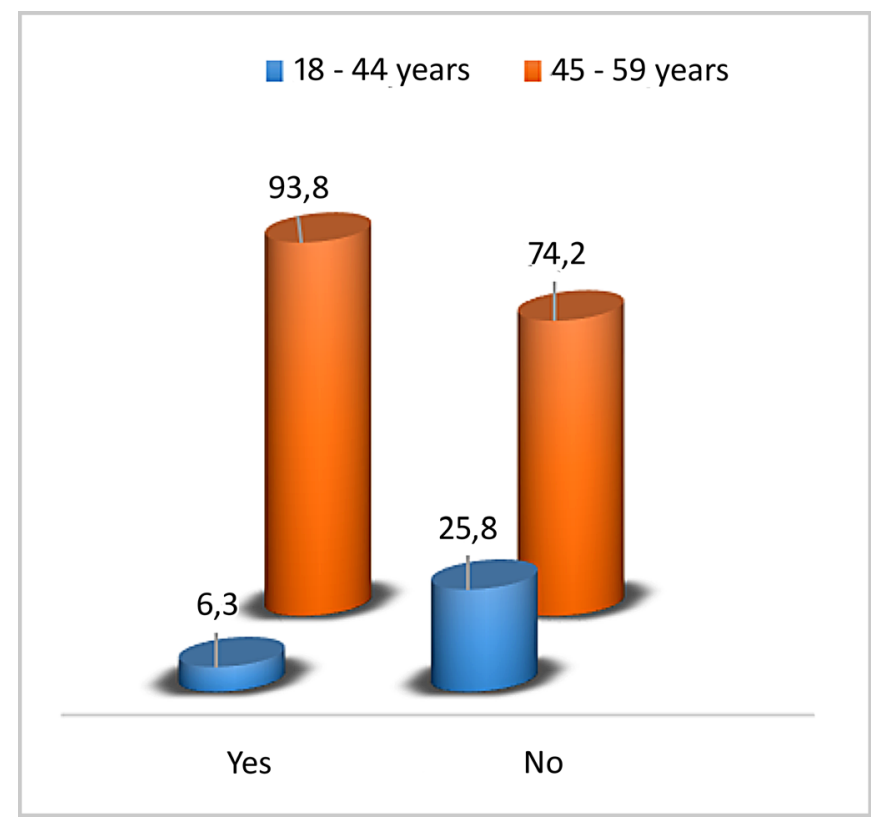

The experiments were conducted in accordance with the rules and regulations approved by the University Research Ethics Committee. Informed consent was obtained by the patients or their authorized relatives.

Detailed information concerning history of disease, family history, behavioral and risk factors, previous and concomitant medication, was collected.

The National Institute of Health Stroke Scale (NIHSS) was used to assess the neurological deficit on admission and the modified Rankin Scale (mRS) was used to evaluate the outcome at discharge.

All the patients underwent CT examination of the brain on admission. Routine blood tests were done on admission, including serum lipid profile (total cholesterol, LDL, HDL and triglycerides), blood glucose and C-reactive protein (CRP).
For the identification of RF for ischemic stroke different categorical and quantitative variables were used. The categorical variables (AH, DM, IS, family history of stroke, smoking, alcohol consumption, low physical activity, overweight) were defined by their absolute and relative frequency. The quantitative variables (LDL, HDL, CRP, blood glucose, systolic and diastolic blood pressure) were presented by median (Mdn), minimal and maximal values (Min $\div$ Max). The statistical analysis was performed with the Statistical Package for Social Sciences, version 24.0 (SPSS). Pearson's chi-squared test $\left(\chi^{2}\right)$ and MannWhitney $U$ test were also used. A value of $\mathrm{p} \leq 0.05$ was considered statistically significant.

\section{RESULTS}

Data concerning the distribution of patients by sex and age are given in Table 1. The results showed that 42 $(66.7 \%)$ of the patients with IS were male and $53(84.1 \%)$ were middle-aged. The incidence of stroke was similar for both sexes in the group of young patients $(n=5 ; 50 \%)$ while $37(69,8 \%)$ of middle-age cases were predominantly males, statistically nonsignificant difference $(\mathrm{p}=0.223)$. Family history of stroke was found in 30 (93.8\%) of the middle-aged patients with acute IS and only in $2(6,3 \%)$ of the young ones $(\chi 2=4.510 ; \mathrm{df}=1 ; \mathrm{p}=0.034)$. (Fig. 1 )

Table 1. Distribution of patients with IS by sex and age $(\mathrm{n}, \%)$

\begin{tabular}{|l|c|c|c|}
\hline Variable & $\mathbf{n}(\boldsymbol{\%})$ & Variable & $\mathbf{n}(\boldsymbol{\%})$ \\
\hline Sex & & Age & \\
Male & $42(66.7)$ & $18-44 \mathrm{y}$ & $10(15.9)$ \\
Female & $21(33.3)$ & $45-59 \mathrm{y}$ & $53(84.1)$ \\
\hline Total & $63(100.0)$ & Total & $63(100.0)$ \\
\hline
\end{tabular}

The most common behavioral RF for IS (total and for the two subgroups) are presented on Table 2. Smokers dominated in the middle-age $B$ group $(n=45 ; 71,4 \%)$, though the difference was not statistically significant $(\mathrm{p}=0,380)$. About $51 \%$ of the smokers had history of tobacco smoking $>10$ years. Comparatively higher $(31,8 \%)$ was the number of young heavy smokers ( $>20$ cigarettes/ daily). Alcohol consumption was declared by $83 \%$ of the middle-age IS patients $(\mathrm{p}=0.869)$, but everyday alcohol consumption was more common for the young IS patients $(92,9 \%)$. Body overweight was more frequent in the middle-age patients $(90,5 \%)$. Low physical activity (less than 30 min daily walking) had only $20 \%$ of the young IS patients and $80 \%$ of the middle-age IS cases $(p=0,619)$. 
Table 2. Distribution of the behavioral RF for acute IS (n, \%), total and by groups.

\begin{tabular}{|l|c|c|c|c|}
\hline Variable (n, \%) & Total & $\begin{array}{c}\text { Group A } \\
(\mathbf{1 8 - 4 4} \mathbf{y})\end{array}$ & $\begin{array}{c}\text { Group B } \\
\mathbf{4 5 - 5 9} \mathbf{y})\end{array}$ & p \\
\hline Smoking (smokers) & $45(71.4)$ & $8(17.8)$ & $37(82.2)$ & 0.513 \\
\hline $\begin{array}{l}\text { Number of smoked cigarettes } \\
\text { e’20 cigarettes/daily }\end{array}$ & $26(41.3)$ & $20(31.8)$ & $6(26.1)$ & 0.380 \\
\hline $\begin{array}{l}\text { Alcohol consumption (AC) } \\
\text { Patients with AC }\end{array}$ & $30(47.6)$ & $5(16.7)$ & $25(83.3)$ & 0.869 \\
\hline Frequency of AC Everyday AC & $14(22.2)$ & $13(92.9)$ & $1(7.1)$ & 0.434 \\
\hline $\begin{array}{l}\text { Body overweight Patients with body } \\
\text { overweight }\end{array}$ & $21(33.3)$ & $2(9.5)$ & $19(90.5)$ & 0.326 \\
\hline Low Physical activity (LPA) LPA & $27(42.9)$ & $5(18.5)$ & $22(81.5)$ & 0.619 \\
\hline
\end{tabular}

Data about the incidence and prevalence of traditional RF for ischemic stroke are given in Table 3. Hypertension was the major risk factor in $90 \%$ of the acute IS patients, 7 times more frequent in the middle-age $(87,3 \%)$ compared to the young $(12,7 \%)$ IS patients, though the difference was not statistically significant $(\mathrm{p}=0,073)$. Young patients had mean blood pressure (BP) $135 / 90 \mathrm{mmHg}$ (systolic BP $110 \div 220$ and diastolic BP
$75 \div 120$ ), while middle-age patients had mean BP 140/90 (systolic BP $110 \div 250$ and diastolic $70 \div 130)(p>0,05)$. Diabetes had $20(31,8 \%)$ patients with acute IS and it was more frequently associated with the middle-age cases $(87.3 \%)(\mathrm{p}=0.541)$. The lipid profiles of both groups were similar. Though CRP mean values were higher in group A $(6.2 ; 1.4 \div 41.8)$ compared to group B $(3.9 ; 0.5 \div 29.1)$, a statistical significance was not found $(\mathrm{p}=0.130)$.

Table 3. Distribution of the traditional RF for IS, total and by groups

\begin{tabular}{|c|c|c|c|c|}
\hline Variable $(\mathrm{n}, \%)$ & Total & $\begin{array}{l}\text { Group A } \\
(18-44 \text { y) }\end{array}$ & $\begin{array}{l}\text { Group B } \\
(45-59 \text { y) }\end{array}$ & $\mathbf{p}$ \\
\hline $\begin{array}{l}\text { Arterial hypertension }(\mathrm{AH}) \\
\text { Yes, present }\end{array}$ & $55(87.3)$ & $7(12.7)$ & $48(87.3)$ & 0.073 \\
\hline $\begin{array}{l}\text { Diabetes mellitus (DM) } \\
\text { Yes, present }\end{array}$ & $20(31.8)$ & $4(65.7)$ & $16(87.3)$ & 0.541 \\
\hline $\begin{array}{l}\text { Mean values of Total Cholesterol } \\
\text { (Mdn, Min } \div \text { Max) }\end{array}$ & $\begin{array}{c}6,10 \\
(3.6 \div 11.2)\end{array}$ & $\begin{array}{c}6,10 \\
(4.4 \div 9.5)\end{array}$ & $\begin{array}{c}6,10 \\
(3.6 \div 11.2)\end{array}$ & 0.836 \\
\hline $\begin{array}{l}\text { Mean values of HDL } \\
\text { (Mdn, Min } \div \text { Max) }\end{array}$ & $\begin{array}{c}1,20 \\
(0.2 \div 2.4)\end{array}$ & $\begin{array}{c}1,20 \\
(0.8 \div 2.4)\end{array}$ & $\begin{array}{c}1,10 \\
(0.2 \div 1.9) \\
\end{array}$ & 0.292 \\
\hline $\begin{array}{l}\text { Mean values of } L D L \\
\text { (Mdn, Min } \div \text { Max) }\end{array}$ & $\begin{array}{c}3,70 \\
(1.6 \div 7.8)\end{array}$ & $\begin{array}{c}3,50 \\
(2.1 \div 5.7)\end{array}$ & $\begin{array}{c}3,90 \\
(1.6 \div 7.8)\end{array}$ & 0.586 \\
\hline $\begin{array}{l}\text { Mean values of Triglycerides } \\
\text { (Mdn, Min } \div \text { Max) }\end{array}$ & $\begin{array}{c}1,90 \\
(0.4 \div 7.3)\end{array}$ & $\begin{array}{c}1,20 \\
(0.9 \div 5.1)\end{array}$ & $\begin{array}{c}2,10 \\
(0.4 \div 7.3)\end{array}$ & 0.176 \\
\hline $\begin{array}{l}\text { Mean values of } C \text {-reactive protein } \\
\text { (Mdn, Min } \div \text { Max) }\end{array}$ & $\begin{array}{c}4.0 \\
(0.5 \div 41.8)\end{array}$ & $\begin{array}{c}6,20 \\
(1.4 \div 41.8)\end{array}$ & $\begin{array}{c}3,90 \\
(0.5 \div 29.1)\end{array}$ & 0.130 \\
\hline
\end{tabular}

\section{DISCUSSION}

In the present study we compared the incidence and prevalence of RF in young and middle-age acute IS patients. We found that in the middle-aged group male patients prevailed, while in the group of young patients both sexes had a similar frequency of IS $(\mathrm{p}=0.223)$. According to the study of Miri Lutski et al. the young patients with IS were predominantly male smokers with a family his- tory of IS. [6] A research on 15257 patients confirmed that the incidence of IS increased with age, but in young patients, less than 44 years old, it was higher for the female ones (53\%) [7]. Although family history of stroke was defined as independent nonmodifiable risk factor, current data concerning the association between family history and the risk for developing IS have been controversial [8]. We found high percentage of first-degree fam- 
ily history of stroke only in the middle-age IS patients (Group B).

Recently INTERSTROKE study proved the major role of the following RF for IS: current smoking, alcohol consumption, stress, low physical activity, irrational nutrition, obesity, dyslipidemia, DM, AH and cardiac diseases. All of them were defined as modifiable RF, responsible for $90 \%$ of strokes [9]. Our results demonstrated that arterial hypertension was the major IS risk factor $(87,3 \%)$, followed by current smoking $(71,4 \%)$; low physical activity $(42,9 \%)$; body overweight $(33,3 \%)$; diabetes mellitus $(31,8 \%)$ and daily alcohol consumption $(22,2 \%)$ (Table 2 and 3). This finding is different from the data published by Bettina von Sarnowski et al., where smoking was the leading RF $(55,5 \%)$, followed by low physical activity $(48,2 \%)$, AH $(46,6 \%)$, dyslipidemia $(34,9 \%)$ and obesity $(22,3 \%)[5]$.

The risk of IS was found to be 2 to 4 times greater in smokers $[10,11]$, what is more, it was defined as dose dependent, especially for patients younger than 44 years [12]. In our study $71 \%$ of all the patients with acute IS were smokers, with a distinct prevalence of the middleage patients.

Alcohol consumption was 5 times higher in the group of middle-age IS patients compared to the young ones $(\mathrm{p}=0.8369)$. More than $90 \%$ of the young strokes declared everyday alcohol consumption, to as only $7 \%$ of the middle-age cases $(\mathrm{p}=0.434)$. Everyday alcohol consumption was associated with increased risk of IS [13], and that risk was greater for patients, younger than 65 years [14, 15]. A disadvantage of the present study was the lack of detailed information concerning the quantity and type of alcohol intake, which should be corrected in future prospective studies.

Obesity is considered a significant modifiable risk factor, especially for young IS patients [16]. According to our results, body overweight was found in $90 \%$ of the middle-age IS patients, not in the young ones.

Low physical activity is another risk factor for IS that offers an excellent option for primary prevention in young adults $[17,18,19]$. The prevalence of low physical activity in the middle-age group was 4 times higher than in young IS patients $(\mathrm{p}=0.619)$.

$\mathrm{AH}$ was 7 times more frequent risk factor in the middle-age IS patients, compared to the young ones $(p=0.073)$. Recent data revealed that $41,8 \%$ from the Bulgarian population have $\mathrm{AH}$ and $72 \%$ of the patients with stroke have AH, too [20]. According to Michael McManus and David S Liebeskind AH is the major modifiable risk factor present in about $84 \%$ of IS patients. [21]. Our results are identical with the published data, showing similar mean BP values of the compared groups with systolic $\mathrm{BP}$ on admission $>140 \mathrm{mmHg}$ being registered in more than $50 \%$ [21].

DM is an important modifiable RF for IS as patients with $\mathrm{DM}<65$ years old have 5 times higher risk of IS compared to those without DM at the same age [22]. J. Putaala et al. also reported that younger patients with IS and DM had increased vascular risk [23]. We found that middleage IS patients had a higher incidence of DM (87.3\%), but statistically nonsignificant.

Dyslipidemia is associated with atherosclerotic plaque formation of the extra- and intracranial vessels, thus increasing the risk of IS [24, 25]. Dyslipidemia is intimately connected with cerebrovascular disease because of the strong dependence between the total cholesterol level (>7mmol/1), LDL cholesterol and the risk of IS [26]. The comparative analysis of our patients' lipid profiles showed elevated total cholesterol $(p=0.836)$, lower HDLcholesterol $(p=0.292)$ and higher LDL-cholesterol $(p=0.586)$ for both of the studied groups. Epidemiological studies have provided conflicting findings regarding the association of dyslipidemia with ischemic stroke [26].

$\mathrm{C}$-reactive protein is a nonspecific biomarker of inflammation, being defined lately as a predictor of increased vascular risk for IS [27]. From our results young IS patients had higher mean values of CRP, compared to those of the middle-age group, but statistically non-significant $(\mathrm{p}=0,130)$.

\section{CONCLUSION}

Our results confirm data from previous research, but are limited by the small sample size. At the same time, some interesting relations were found. A prevalence of the modifiable risk factors as smoking, alcohol consumption, obesity, low physical activity, AH and DM was found in the group of middle-aged acute IS patients compared to the young ones. Alcohol consumption and heavy smoking were identified as significant risk factors for the young acute IS patients.

Future prospective large population-based studies could improve our basic knowledge on the potentially modifiable risk factors specific for young adults.

\section{ACKNOWLEDGEMENTS}

This article is supported under Project No 6/2018 of Medical University Pleven.

\section{REFERENCES:}

1. [National consensus on prevention, diagnosis and treatment of cerebrovascular diseases.] Edited by Milanov I, Stamenova P, Casso V. J Bulgarian Neurology. 2018 Jan;19 (Suppl 1):2-32. [in Bulgarian] [nternet]

2. Goeggel Simonetti B, Mono ML,
Huynh-Do U, Michel P, Odier C, Sztajzel R, et al. Risk factors, aetiology and outcome of ischaemic stroke in young adults: the Swiss Young Stroke Study (SYSS). J Neurol. 2015 Sep;262(9):2025-32. [PubMed] [Crossref]

3. Smajlovic D. Strokes in young adults: epidemiology and prevention. Vasc Health Risk Manag. 2015 Feb 24;11:157-64. [PubMed] [Crossref]

4. Schneider S, Kornejeva A, Vibo R, Korv J. Risk Factors and Etiology of Young Ischemic Stroke Patients in Estonia. Stroke Res Treat. 2017; 2017 : 8075697. [PubMed] [Crossref] 
5. von Sarnowski B, Putaala J, Grittner U, Gaertner B, Schminke U, Curtze $\mathrm{S}$, et al. Lifestyle risk factors for ischemic stroke and transient ischemic attack in young adults in the Stroke in Young Fabry Patients study. Stroke. 2013 Jan;44(1):119-25. [PubMed] [Crossref]

6. Lutski M, Zucker I, Shohat T, Tanne D. Characteristics and Outcomes of Young Patients with First-Ever Ischemic Stroke Compared to Older Patients: The National Acute Stroke ISraeli Registry. Front Neurol. 2017 Aug 21;8:421. [PubMed] [Crossref]

7. Ekker MS, Verhoeven JI, Vaartjes I, van Nieuwenhuizen KM, Klijn CJM, de Leeuw FE. Stroke incidence in young adults according to age, subtype, sex, and time trends. Neurology. 2019 May 21;92(21):e2444-e2454. [PubMed] [Crossref]

8. Choi JC, Lee JS, Kang SY, Kang $\mathrm{JH}$, Bae JM. Family history and risk for ischemic stroke: sibling history is more strongly correlated with the disease than parental history. J Neurol Sci. 2009 Sep 15;284(1-2):29-32. [PubMed] [Crossref]

9. O'Donnell MJ, Chin SL, Rangarajan S, Xavier D, Liu L, Zhang $\mathrm{H}$, et al. Global and regional effects of potentially modifiable risk factors associated with acute stroke in 32 countries (INTERSTROKE): a case-control study. Lancet. 2016 Aug 20;388 (10046):761-75. [PubMed] [Crossref]

10. Shah RS, Cole JW. Smoking and stroke: the more you smoke the more you stroke. Expert Rev Cardiovasc Ther. $2010 \mathrm{Jul} ; 8(7): 917-32$. [PubMed] [Crossref]

11. Epstein KA, Viscoli CM, Spence JD, Young LH, Inzucchi SE, Gorman M, et al. Smoking cessation and outcome after ischemic stroke or TIA. Neurology. 2017 Oct 17;89(16): 1723-1729. [PubMed] [Crossref]

12. Markidan J, Cole JW, Cronin
CA, Merino JG, Phipps MS, Wozniak MA, et al. Smoking and Risk of Ischemic Stroke in Young Men. Stroke. 2018 May;49(5):1276-8. [ [PubMed] [Crossref]

13. Mukamal KJ, Ascherio A, Mittleman MA, Conigrave KM, Camargo CA Jr, Kawachi I, et al. Alcohol and risk for ischemic stroke in men: the role of drinking patterns and usual beverage. Ann Intern Med. 2005 Jan 4;142(1):11-9. [PubMed] [Crossref]

14. Mostofsky E, Burger MR, Schlaug G, Mukamal KJ, Rosamond WD, Mittleman MA. Alcohol and acute ischemic stroke onset: the stroke onset study. Stroke. 2010 Sep;41(9): 1845-9. [PubMed] [Crossref]

15. Mustanoja S, Putaala J, Gordin D, Tulkki L, Aarnio K, Pirinen J, et al. Acute-Phase Blood Pressure Levels Correlate With a High Risk of Recurrent Strokes in Young-Onset Ischemic Stroke. Stroke. 2016 Jun;47(6):15938. [PubMed] [Crossref]

16. Aigner A, Grittner U, Rolfs A, Norrving B, Siegerink B, Busch MA. Contribution of Established Stroke Risk Factors to the Burden of Stroke in Young Adults. Stroke. $2017 \mathrm{Jul}$; 48(7):1744-1751. [PubMed] [Crossref]

17. Deplanque D, Masse I, Libersa C, Leys D, Bordet R. Previous leisuretime physical activity dose dependently decreases ischemic stroke severity. Stroke Res Treat. 2012;2012:614925. [ [PubMed] [Crossref]

18. Mostofsky E, Laier E, Levitan EB, Rosamond WD, Schlaug G, Mittleman MA. Physical activity and onset of acute ischemic stroke: the stroke onset study. Am J Epidemiol. 2011 Feb 1;173(3):330-6. [PubMed] [Crossref]

19. Lee CD, Folsom AR, Blair SN. Physical activity and stroke risk: a meta-analysis. Stroke. 2003 Oct;
34(10):2475-81. [PubMed] [Crossref]

20. Titianova E, Velcheva I, Andonova S. Stroke in Bulgaria: Recent Problems. Neurosonology and Cerebral Hemodynamics. 2015 May;11(1):7-13. [Internet]

21. McManus M, Liebeskind DS. Blood Pressure in Acute Ischemic Stroke. J Clin Neurol. 2016 Apr;12(2):137-46. [PubMed] [Crossref]

22. Khoury JC, Kleindorfer D, Alwell K, Moomaw CJ, Woo D, Adeoye $\mathrm{O}$, et al. Diabetes mellitus: a risk factor for ischemic stroke in a large biracial population. Stroke. 2013 Jun;44(6):1500-4. [PubMed] [Crossref]

23. Putaala J, Liebkind R, Gordin D, Thorn LM, Haapaniemi E, Forsblom C, et al. Diabetes mellitus and ischemic stroke in the young: clinical features and long-term prognosis. Neurology. 2011 May 24;76(21): 1831-7. [PubMed] [Crossref]

24. Tziomalos K, Athyros VG, Karagiannis A, Mikhailidis DP. Dyslipidemia as a risk factor for ischemic stroke. Curr Top Med Chem. 2009; 9(14):1291-7. [PubMed] [Crossref]

25. Tai MLS, Yuin Liew JS, Sheun Mo SY, Elwaifa MA. 5. Risk Factors in the Patients with Extracranial Carotid Atherosclerosis. In: Peripheral Arterial Disease - A Practical Approach. Edited by Sareen N, Ojha A. IntechOpen. October 17th 2018, Chapter5: pp.228. [Crossref]

26. Yaghi S, Elkind MS. Lipids and Cerebrovascular Disease: Research and Practice. Stroke. 2015 Nov;46(11): 3322-8. [PubMed] [Crossref]

27. Ladenvall C, Jood $\mathrm{K}$, Blomstrand C, Nilsson S, Jern C, Ladenvall P. Serum C-reactive protein concentration and genotype in relation to ischemic stroke subtype. Stroke. 2006 Aug;37(8):2018-23. [PubMed] [Crossref]

Please cite this article as: Dimitrov GT, Danovska MP, Simeonova YI, Gencheva II, Stoev PG, Ovcharova EM, Marinova DL. Comparative Evaluation of Risk Factors in Young and Middle-Age Patients with Acute Ischemic Stroke. $J$ of IMAB. 2020 Jan-Mar;26(1):2926-2930. DOI: https://doi.org/10.5272/jimab.2020261.2926

Received: 12/09/2019; Published online: 20/02/2020

Address for correspondence:

Dr Georgi Tzvetanov Dimitrov

Department of Neurology and Neurosurgery, Medical University - Pleven;

1, St. Kliment Ochridski Str., Pleven, 5800, Bulgaria.

E-mail: georgi_cdimitrov@abv.bg 